\title{
Effects of Judo Strength-Velocity Training during Precompetition on Cardiorespiratory Responses in Congolese Judoists Aged 15 - 17 Years Old
}

\author{
Jean Georges André Moulongo ${ }^{1,2 *}$, Alphonse Massamba1,3, Jean Marie Kayembe Ntumba4, \\ François Lepira Bompeka4, Félix Lotoko Lisule ${ }^{5}$, Bernard Packa-Tchissambou ${ }^{1}$ \\ ${ }^{1}$ Laboratory for Exercise Physiology and Biomechanics, Higher Institute of Physical Education and Sports (ISEPS), University Marien \\ NGOUABI, Brazzaville, Congo \\ ${ }^{2}$ Direction of Research, Documentation and the Files, National Institute of Youth and Sports (INJS), Brazzaville, Congo \\ ${ }^{3}$ Laboratory of Biomaterials, Health and Simulation of the Processes, Higher School of Technology of the Cataracts, Brazzaville, Congo \\ ${ }^{4}$ Faculty of Medicine, University of Kinshasa, Kinshasa, Congo \\ ${ }^{5}$ Department of Physical Education, National Teaching University, Kinshasa, Congo \\ Email: `jgamoulongo@gmail.com
}

How to cite this paper: Moulongo, J.G.A., Massamba, A., Kayembe Ntumba, J.M., Lepira Bompeka, F., Lotoko Lisule, F. and Packa-Tchissambou, B. (2016) Effects of Judo Strength-Velocity Training during Precompetition on Cardiorespiratory Responses in Congolese Judoists Aged 15 - 17 Years Old. Journal of Biosciences and Medicines, 4, 50-64.

http://dx.doi.org/10.4236/jbm.2016.410006

Received: August 30, 2016

Accepted: October 16, 2016

Published: October 19, 2016

Copyright $\odot 2016$ by authors and Scientific Research Publishing Inc. This work is licensed under the Creative Commons Attribution International License (CC BY 4.0).

http://creativecommons.org/licenses/by/4.0/

(c) (i) Open Access

\section{Abstract}

Objective: To evaluate the effects of "strength-velocity" training on the evolution of some cardiorespiratory parameters in postpubertal judoists of the Congolese national elite. Methods: The survey, exploratory, experimental and longitudinal, was about 14 boys, belonging to seven categories of weight of the International Federation of Judo. These judoists, at the level belonged to stages 3, 4 and 5 of the classification to Tanner, of pubertal maturation. Their median age was 16 years (range: 15 - 17 years). All topics have been submitted to "strength-velocity" training, focused around exercises bound to the development of the power and automatisms, from plyometric and isometric training. Three assessments have been realized in the beginning, to midtraining ( 3 months) and at the end of the program ( 6 months). The measured values were cardiorespiratory parameters. Results: The heart rate to the doorstep was decreased significantly $(\mathrm{p}=0.048)$, so $\mathrm{VO}_{2} \max (\mathrm{p}=0.046), \mathrm{FVC}(\mathrm{p}=0.0244)$ and ratio VEMS/FVC ( $p=0.046)$ as function of pubertal stage. In contrast, increase was not significant for VEMS $(\mathrm{p}=0.205)$ and absolute $\mathrm{VO}_{2}$ to doorstep $(\mathrm{p}=0.097)$. No significant effect of pubertal state on respiratory frequency was found. On the other hand, strength-velocity training improved cardiorespiratory data. To the recovery of the "strength-velocity test", the decrease of the $\mathrm{VO}_{2}$ took place more quickly that the one of the VE, the $\mathrm{VCO}_{2}$ and the $\mathrm{HR}$, variations linked to the category of topic weight. Conclusion: Among high level Congolese postpubertal judoists, the cardiorespiratory modifications induce faculty to the realization of a good performance 
and pursue objectives of health. However, it is necessary to be heedful as for situations to put in place in sittings at the time of such of "strength-velocity" training.

\section{Keywords}

Judo, Postpuberty, Strength-Velocity Training, Cardiorespiratory Modifications

\section{Introduction}

Complex problems are linked to the research of the performance for an athlete. Today, in spite of the improvement of the techniques, the infrastructures and the organization, the accession on the most level cannot be considered without a network of systems and models of all kinds which took part in the optimization of performance. Detection and formation of elite sportsman, early nowadays [1], are regarded as inter alia fundamental factors of the success around whose physiological follow-up medical-training [2] organizes. The increasingly perfect knowledge of the physiological capacities brought into play in the high level sporting preparation makes it possible to better define the adaptations to the training, to specify its effects, and to control its progression. Recent studies on power (strength-velocity) indicate that the men parameters involving in the muscle mechanics during this training program are: the number (myosin-actin cross-bridges in parallel (maximal force), the composition of myosin heavy chains, the activity of myofibrillar ATPases (maximal velocity of shortening), and the concentrations of $\mathrm{H}+$ and $\mathrm{Pi}$ (muscle fatigue) [3]-[6]. These studies also show that training induces the following physiological adaptations: fiber hypertrophy, transformation from to IIb fibers towards IIa fibers, an increase in resistance to fatigue, notably cardiorespiratory modifications. If studies are available for the majority of the sports, few works exist on the fighting sports of the judo [5]. However, the judo is a technical and strategic fighting sport causing significant energy expenditure, and the trainers must integrate inter alia the unit cardiorespiratory adaptations in the preparation of athletes.

It is in this direction that the practice of the judo caused some studies on the importance of the request of the physiological adaptations [7]. The practice of the high level judo, sport comprising seven categories of weight, requires training from 25 to 30 hours weekly and a severe control of the weight. However, this can have physiological consequences at the subject not mast [8]. It is in this context that at the child and the teenager, very few studies were devoted on the cardiorespiratory adaptations. Moreover, the listed data are contradictory [9]. Indeed, the majority of the studies, cross-sectional, do not make it possible to account for the variations of maturation in children of different categories of age [10]. However, the design "cross-sectional" and not "longitudinal" doesn't allow the dynamic evaluation of the parameters of interest in time. However, the process of training in power (strength-velocity) which rests the practice of the modern judo was adopted as from the post-puberty period.

In comparison with our lived sportsman as a trainer of judo and the observations on 
the way in which the Congolese trainers build their strategy in the preparation of African Championships of Judo of 2016, we put ourselves the question of following research: does the mode of training Strength-Velocity (S-V) contribute to the junior judoists (15 - 17 years) to modify the cardiorespiratory capacities of the old judoists by taking account of puberty maturation in progress? From this question, the aim of this study is to contribute to a better knowledge of cardiorespiratory factors of the performance at the time of training in S-V in the Congolese high level judoists in puberty period. The aim of this study is to evaluate the effects of training in S-V on the cardiorespiratory adaptations in the Congolese judoists aged 15 to 17 years old. The specific objectives were to evaluate respiratory and ventilatory state [expiratory volume (EV), total ventilatory $\left(\mathrm{V}_{\mathrm{T}}\right)$, oxygen volume uptake $\left(\mathrm{VO}_{2}\right)$, ratio $\mathrm{VO}_{2} / \mathrm{HR}$ (pulse of $\mathrm{O}_{2}$ ), maximal oxygen uptake $\left(\mathrm{VO}_{2} \mathrm{max}\right)$, volume of dioxide carbone $\left(\mathrm{VCO}_{2}\right)$, respiratory quotient (RQ), forced vital capacity (FVC), volume expired per minute (VEMS), ratio VEMS/ FVC, respiratory frequency (FR)] noted before, mid and after the training program.

\section{Material and Methods}

\subsection{Type and Tally of the Study}

The study, experimental and longitudinal, was conducted at Makelekele' Sporting and University Center of SUCM, from March $19^{\text {th }}$ to August $19^{\text {th }} 2016$, in Brazzaville, capital of the Republic of Congo. These 6 months corresponds in the physical and sporting activities to the period of preselection and precompetition to the high level [11].

\subsection{Sampling}

The population source was made up of the Congolese judoists old from 15 to 17 years (junior category). The population target was summarized with the judoists of the aforementioned category of age, selected for the training of the national team of judo within the framework of the African Games 2015. According to the criteria of selection retained by the national trainers and while being based on the rules enacted by the International Federation of Judo (I.F.J) on the composition of the teams, 21 judoists were recruited. All these subjects, were subjected to a medical examination including/understanding cardiovascular examinations (blood pressure, electrocardiography, echocardiography), pulmonary radiography, respiratory (respiratory frequency, FR) and ventilatory $\left(\mathrm{VO}_{2}, \mathrm{VCO}_{2}, \mathrm{VE}, \mathrm{V}_{\mathrm{T}}, \mathrm{VO}_{2} \max \right)$ examinations, biochemical examinations [plasma volume (PV), numeration formulate blood (NFB), total number of erythrocytes, total number of plates, rate of hemoglobin, rate of hematocrite, average globular volume) and a biochemical assessment (glycemia, lactatemia, magnesemia). A team of judo comprises seven (07) judoists, each one of them belonging to the 7 categories of weight retained by the International Federation of Judo (I.F.J). With the data obtained from the examination, the subjects which presented factors of cardiorespiratory risks for the practice of the training in power were excluded. Thus, on the basis of criterion of selection of the national trainers, 28 judoists, constituted the starting sample during the period of study which corresponded to the precompetitive preparation of quoted 
tournaments. The Figure 1 is also explained by the official composition of a team of judo, namely a judoist by category of weight, each one of them having a lining. Because of work per pair, of the obligation to engage a reserve judoist by category and to increase the volume of training, a team of 7 other judokas was made up. So, the sampling of selected subjects was equal to 35 . They were all of male sex. Thus, the experimentation related to 35 judoists. They were divided into three groups: group 1, 7 titular judoists; group 2, 7 judoists of the reserves teams and group 3, 21 judoists reinforcing groups 1 and 2 in order to increase the volume of work. However, only the subjects of groups 1 and $2(\mathrm{~N}=14)$ constituted the final sample. The anthropometric characteristics of the subjects of the whole group are presented in Table 1 .

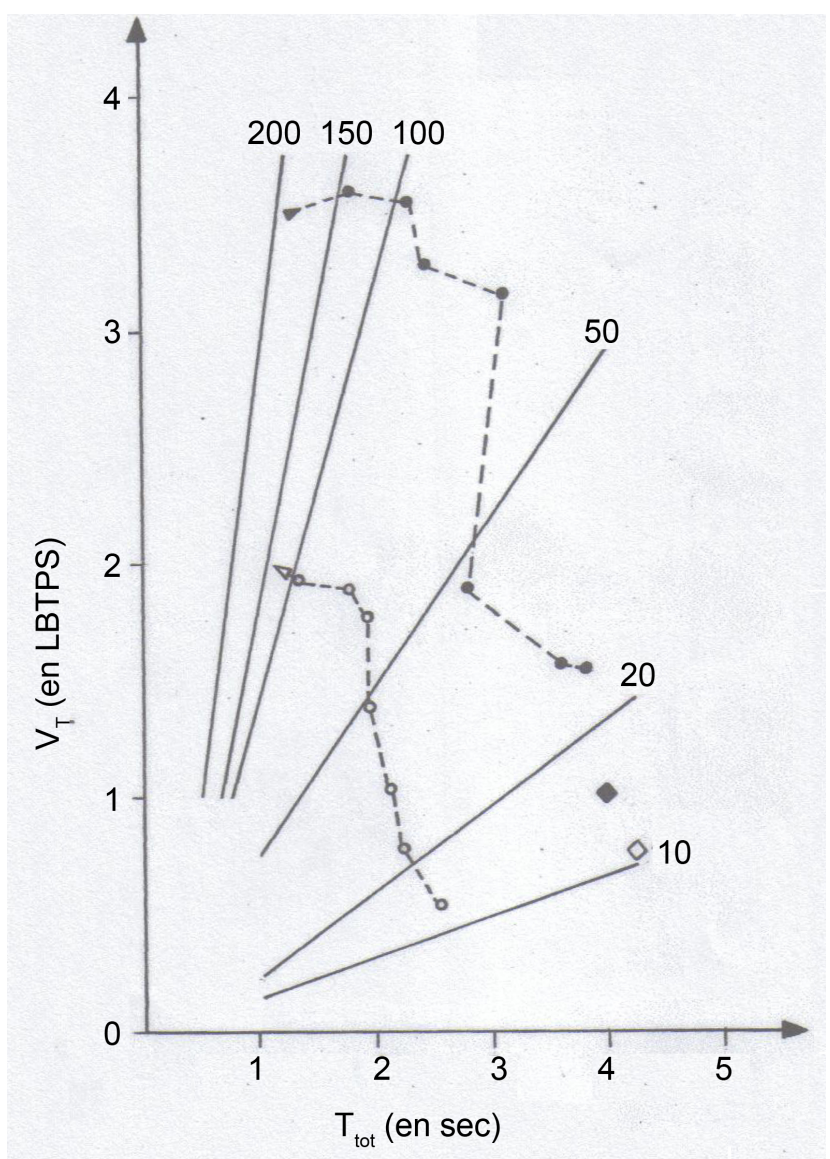

Figure 1. Ventilatory mode during recovery at the end of the program. The combination of volume running $\left(\mathrm{V}_{\mathrm{T}}\right.$ and of the period $\left(\mathrm{T}_{\text {tot }}=60 / \mathrm{FR}\right)$ allows the construction of isolines of ventilatory flows (oblique, VE) expressed in LBTPS. $\mathrm{min}^{-1}$. The clear symbols represent the judoists of $80 \mathrm{~kg}$ to more than $100 \mathrm{~kg}$, the closed symbols those of less than $80 \mathrm{~kg}$. The rhombuses represent the starting values (rest), the triangles the actual values at the end of the exercise. The evolution of the ventilatory mode, $\mathrm{V}_{\mathrm{T}}$ during recovery is indicated by the 30 second old rounds ( $1^{\text {st }}$ point after the triangle) to $10 \mathrm{mi}$ nutes (the last point). 
Table 1. Anthropometric characteristics of the whole of the subjects.

\begin{tabular}{ccc}
\hline & $\mathrm{X} \pm \mathrm{S}(\mathrm{n}=14)$ & Range \\
\hline Height $(\mathrm{cm})$ & $176.1 \pm 3.1$ & $165-187$ \\
Weight $(\mathrm{kg})$ & $54.0 \pm 8.5$ & $59-104$ \\
BMI $\left(\mathrm{kg} / \mathrm{m}^{2}\right)$ & $19.6 \pm 2.2$ & $18.9-29.7$ \\
\hline
\end{tabular}

BMI: Body Mass Index.

The distribution of the judoists in groups 1 and 2 was carried out by the trainers, by taking account of their gauge (in particular size). The median age of the subjects of groups 1 and 2 was 16 years (range: 15 - 17 years). Bone maturity was determined from the left hand and wrist by $\mathrm{x}$-ray photos measuring the RUS score developed by Tanner et al. [12]. So, these subjects were examined by a pediatric and an endocrinologist. Three (3) puberty classes were found.

\subsection{Variables}

The studied variables were heart rate [noted before, mid (3 months) and after at the time of the last randori carried out at the end of a training sequence], intensities of exercises (IW), forced vital capacity (FVC) before the program, maximum expiratory volume per second (VEMS) before training program, ratio VEMS/FVC before training program, the respiratory frequency $(\mathrm{FR})$ before training program, oxygen uptake $\left(\mathrm{VO}_{2}\right)$ [noted before, mid ( 3 months), after training program and during the recovery period $(\mathrm{t}=0 \mathrm{~s} ; \mathrm{t}=1.30 \mathrm{~min} ; \mathrm{t}=4.30 \mathrm{~min} ; \mathrm{t}=7 \mathrm{~min}$ and $10 \mathrm{~min})$ ], volume of carbon dioxide $\left(\mathrm{VCO}_{2}\right)$ [noted before, mid (3 months) and after training program], respiratory quotient (RQ) equal to $\mathrm{VCO}_{2} / \mathrm{VO}_{2}$ [evaluated before, mid (3 months) and after the training program], total volume $\left(\mathrm{V}_{\mathrm{T}}\right)$ [noted before, mid (3 months), after training program and during the recovery period: $\mathrm{t}=0 \mathrm{~s} ; \mathrm{t}=1.30 \mathrm{~min} ; \mathrm{t}=4.30 \mathrm{~min} ; \mathrm{t}=7 \mathrm{~min}$ and $10 \mathrm{~min}$ ], ventilation minute (VE) [noted before, mid ( 3 months), after training program and during the recovery period: $\mathrm{t}=0 \mathrm{~s} ; \mathrm{t}=1.30 \mathrm{~min} ; \mathrm{t}=4.30 \mathrm{~min} ; \mathrm{t}=7 \mathrm{~min}$ and $10 \mathrm{~min}$ ], and maximum oxygen uptake $\left(\mathrm{VO}_{2} \max \right)$ [noted before, mid ( 3 months), after training program and during the recovery period: $\mathrm{t}=0 \mathrm{~s} ; \mathrm{t}=1.30 \mathrm{~min} ; \mathrm{t}=4.30 \mathrm{~min} ; \mathrm{t}=7 \mathrm{~min}$ and $10 \mathrm{~min}]$. The experimental study was based on the statement of the variables above mentioned. All the protocols were realized according to the recommendations by the French Sport Medicine Society for the physical capacity [13].

\subsection{Determination of the Respiratory and Ventilatory Variables}

For this purpose, all subjects underwent an incremental exercise test on cycloergometer Ergoline 600S. The frequency of cycling was fixed at 50 revolutions per minute. No alterations were made in the ratio of flywheel to pedal revolutions from that of the standard Ergoline cycloergometer. The test was carried out at the Laboratory of Exercise Physiology and Biomechanics of the Higher Institute of Physical Education and Sports, Marien NGOUABI University (Brazzaville, Congo). The test proceeded between 8:00 and 10:00, after a sleep of average duration 9 hours approximately. The temperature 
within the Laboratory comprised between $22^{\circ} \mathrm{C}-24^{\circ} \mathrm{C}$, relative humidity of the ambient air to $76 \%$. One day before the test, the subjects were familiarized with the cycloergometric test. During the muscular exercise, the subjects breathed through a valve of low resistance (dead space of $90 \mathrm{ml}$ ) and pipes of large diameter $(3.5 \mathrm{~cm})$. The flows were measured using a standard pneumotachograph no. 3 Fleish (Godard, Stahan, Holland) placed on the inspiratory circuit and connected to a pressure pick-up (MP45, Validyne, Engeneering Corp., CA, the USA), in order to avoid the problems involved in the water vapor. Volumes were obtained by integration of the flows. A fast analyzer of $\mathrm{O}_{2}$ polarophic (OM11, Sensormedics Corp., CA, the USA) and a fast analyzer (with infra-reds) of $\mathrm{CO}_{2}$ (Diamond 6000, Cosma, France), gauged on a gas bottle let us spread out before and after each test, allowed to measure the fraction expired of $\mathrm{O}_{2}\left(\mathrm{FEO}_{2}\right)$ after collection of expired gases in a mixing tube. From the flows of the $\mathrm{FEO}_{2}$ and $\mathrm{FECO}_{2}$ an automated system connected to a computer made it possible to obtain on the basis of 10 respiratory cycles, in BTPS (body temperature and satured pressure) conditions ventilation minute (VE), and in STPD (standard temperature and dry pressure) conditions for peak oxygen uptake $\left(\mathrm{VO}_{2} \mathrm{max}\right)$, according to the equation of Haldane. The test was carried out in an intense way until exhaustion. The criteria suggested to define the $\mathrm{VO}_{2}$ max at the teenagers were as follows: a plate of the $\mathrm{VO}_{2}[14]$, a respiratory quotient lower than 1.15, and an increase in the HR close to the maximum value bordering the maximum HR (HR max) defined by [14]:

$$
\text { HR max }(\mathrm{bpm})=210-(0.65 \times \text { age }) \pm 10
$$

The values of IW were evaluated according to the recommendations by the French Sport Medicine Society for the physical capacity [15]. The forced vital capacity (FVC), maximum expiratory volume per second and the ratio VEMS/FVC were measured thanks to a portable spirometer (Autospira Pal, Minato, Japan).

Experimental work itself was conducted from January $21^{\text {st }}$ to July $17^{\text {th }} 2012$ in Sporting and of Makelekele's University Center (CSUM). The program of training comprised 192 training sequences, divided into 2 meetings per day and this during 4 days per week. Three specific types of drive were used: tandoku-renshyu (training as a recluse), sotai-renshyu (free training without resistance of the partner, with entries in various directions, accompanied by the falls) and sotai-renshyu (with obstacles for the entries).

\subsection{Statistical Analysis}

Because of the lower number of subjects, the test of the Kolmogoroff-Smirnov was carried out in order to be ensured of the normality of the distribution of each variable. The various quantitative data were expressed by their mean accompanied by standard deviation. The test $t$ paired of Student (for weak samples) was used for compare two means. The analysis of variance (ANOVA), on a way and 3 factors, was used for comparing more than 2 means in total randomization, followed a posteriori by test's Bonferonni-Dunn. For comparing 3 percentages, test $S$ of Sokal [16] was used. All statistical analyses were performed with Mathcad, version 9.2 at department of statistics of Brazzaville Faculty of Sciences. P-value $\leq 0.05$ defined statistical significance. 


\subsection{Operational Definitions}

The judo, Olympic discipline, is a physical and sporting activity of gripping having for goal to fight an adversary according to a codified whole of techniques of projection, seizure on the ground, strangulations and arm's keys [11]. A junior judoist is defined as a judoka aged between 15 - 17 years old [1]. The training in strength-velocity is linked to training with a supra-maximum intensity (higher than $80 \%$ of the aerobic maximum power), leading quickly to physical exhaustion [3]. The respiratory values were referred to the recommendations enacted by American Thoracic Society [17].

\subsection{Ethical Considerations}

This study obtained the agreement of the ethics committee of the Medical Company of Congo (SMC) and that of the Congolese Olympic National Committee and Sporting (CNOSC), in accord with the Helsinki II Declaration on ethical standards of the Committee on Human Experimentations.

\section{Results}

The mean values of body weight and BMI of two groups are presented in Table 2. Values of weight of all groups after training program were significantly lower $(\mathrm{p}<0.05)$ than those noted before program: $54.0 \pm 2.0 \mathrm{~kg}$ versus $50.5 \pm 0.8 \mathrm{~kg}$. Higher values of BMI were similar in judoists of two groups; however, these values of whole group increased during training program: $19.4 \pm 1.1 \mathrm{~kg} / \mathrm{m}^{2}$ versus $19.7 \pm 0.5 \mathrm{~kg} / \mathrm{m}^{2}$, no significant difference was observed. Table 3 included evolution of data of HR and IW throughout program.

Table 2. Compared mean values of anthropometric characteristics of the judoists of groups 1 and 2.

\begin{tabular}{ccccc}
\hline & Before program & Mid-program & After program & p-value \\
\hline Weight & & & & \\
Group 1 $(\mathrm{n}=7)$ & $53.2 \pm 2.4$ & $51.7 \pm 9.5$ & $50.6 \pm 1.2$ & 0.043 \\
Group 2 $(\mathrm{n}=7)$ & $54.8 \pm 1.6$ & $52.9 \pm 9.3$ & $54.4 \pm 4.6$ & 0.037 \\
BMI & & & \\
Group 1 $(\mathrm{n}=7)$ & $19.1 \pm 1.5$ & $18.5 \pm 1.8$ & $19.4 \pm 0.6$ & 0.65 \\
Group 2 $(\mathrm{n}=7)$ & $19.6 \pm 0.8$ & $18.9 \pm 1.9$ & $19.9 \pm 0.4$ & 0.72 \\
\hline
\end{tabular}

BMI: Body Mass Index.

Table 3. Mean values and standard deviations of cardiovascular parameters during training program.

\begin{tabular}{cccccc}
\hline & BP & MP & AP & F & p-value \\
\hline HR (b/min) & $54.1 \pm 1.5$ & $51.9 \pm 0.7$ & $51.2 \pm 0.3$ & F $=32.556$ & 0.011 \\
HR $_{\text {ee }}(\mathrm{b} / \mathrm{min})$ & $215.9 \pm 0.4$ & $228.6 \pm 0.1$ & $220.0 \pm 0.2$ & $\mathrm{~F}=223.452$ & 0.004 \\
IW (\%) & $97.5 \pm 0.6$ & $99.6 \pm 0.3$ & $76.7 \pm 0.2$ & $\mathrm{~S}_{0}=0.275$ & 0.012 \\
\hline
\end{tabular}

HR: Heart Rate; HRee: Heart Rate of end of exercise; IW: Intensity Exercise; BP: Before Program; MP: Mid-Program; AP: After Program. 
The values of HR and IW increased significantly $(\mathrm{p}<0.05)$ as the training was carried out, after a rise at mid- program for HR, followed by effort after program: $161.8 \pm$ $0.9 \mathrm{~b} / \mathrm{min}$ versus $168.8 \pm 0.2 \mathrm{~b} / \mathrm{min}$ for HR. However, they dropped particularly for HR at rest. Yet, HR was inversely related to bone maturity scores (RUS) higher than $200(\mathrm{r}=$ $0.32, \mathrm{p}<0.05)$. In addition, the amounts of $\mathrm{HR}_{\mathrm{ee}}$ and IW variations were respectively $+1.9 \%$ and $-3.4 \%$. Evolution data for $\mathrm{VO}_{2}, \mathrm{VO}_{2} \max$, ratio VEMS/FCV and $\mathrm{RF}$ are shown in Table 4. These data showed that the $\mathrm{VO}_{2}$ absolute threshold, HR threshold and $\mathrm{VO}_{2}$ max increased according to the puberty stage. On the other hand, it was about a reduction for the $\mathrm{VO}_{2}$ threshold (in \%). No significant differences were observe between variations of $\mathrm{VO}_{2}$ threshold (in \%), $\mathrm{VO}_{2}\left(\mathrm{ml} / \mathrm{kg} / \mathrm{min}\right.$ ) and $\mathrm{VO}_{2}$ threshold. Moreover, FR was found to be decrease. In addition, evolution of FVC, VEMS and ratio VEMS/FVC (\%) was related to puberty stage. Their variations were found to be significant. Values of FCV and ratio VEMS/FCV increased significantly, according to the puberty stage. However, a decrease was found for RF. The kinetics of respiratory and ventilator data measured during the program are shown in Table 5. As for the modifications of data of these parameters, $\mathrm{VO}_{2}$ varied more quickly between before and after program, followed $\mathrm{VE}, \mathrm{VCO}_{2}$ and $\mathrm{HR}$. Influence of chronological age during development on the kinetics of recovery of respiratory variables is presented in Table 6. It appears that whatever the chronological age considered, recovery was carried out in two phases: a first rapid, a second slow. Whereas, the judoists aged 17 years had a first phase significantly faster $\left(\tau_{1}\right)$ and shorter $\left(\tau_{\Delta}\right)$, except $\mathrm{VO}_{2}$ that of judoists aged 15 years with a second phase $\tau_{2}$ faster. As seen, the evolution of $\mathrm{VO}_{2}$ was faster than $\mathrm{VCO}_{2}$ in first phase, when compared to observations in ventilatory phase 2 .

Table 4. Evolution of the maximum consumption of oxygen, the oxygen uptake to the threshold and the heart rate to the threshold, the forced vital capacity (FVC), of maximum expiratory volume a second (VEMS), ratio VEMS/FVC and the respiratory frequency (RF) according to the puberty age.

\begin{tabular}{|c|c|c|c|c|c|}
\hline & $\begin{array}{c}\text { SP3 } \\
(n=4)\end{array}$ & $\begin{array}{c}\text { SP4 } \\
(n=6)\end{array}$ & $\begin{array}{c}\text { SP5 } \\
(n=4)\end{array}$ & F & p-value \\
\hline $\mathrm{VO}_{2}$ threshold $(1 / \mathrm{min})$ & $1.5 \pm 0.2$ & $1.6 \pm 0.1$ & $1.8 \pm 0.1$ & $\mathrm{~F}=6.000$ & 0.046 \\
\hline $\mathrm{VO}_{2}$ threshold $(\mathrm{ml} / \mathrm{kg} / \mathrm{min})$ & $26.5 \pm 1.3$ & $27.4 \pm 1.7$ & $28.7 \pm 1.2$ & $\mathrm{~F}=2.273$ & 0.131 \\
\hline $\mathrm{VO}_{2}$ threshold (\%) & $56.2 \pm 2.6$ & $56.6 \pm 2.6$ & $59.5 \pm 3.1$ & $\mathrm{~S}_{0}=0.011$ & 0.097 \\
\hline HR threshold (b/min) & $143.1 \pm 4.5$ & $145.6 \pm 4.0$ & $153.6 \pm 6.0$ & $\mathrm{~F}=5.496$ & 0.048 \\
\hline $\mathrm{VO}_{2} \max$ threshold $(1 / \mathrm{min})$ & $2.60 \pm 0.15$ & $2.90 \pm 0.14$ & $3.00 \pm 0.12$ & $F=9.000$ & 0.041 \\
\hline $\begin{array}{l}\mathrm{VO}_{2} \text { max threshold } \\
(\mathrm{ml} / \mathrm{kg} / \mathrm{min})\end{array}$ & $50.2 \pm 1.5$ & $51.2 \pm 1.4$ & $51.4 \pm 1.5$ & $\mathrm{~F}=0.857$ & 0.163 \\
\hline FVC (1) & $2.23 \pm 0.13$ & $2.61 \pm 0.20$ & $3.17 \pm 0.15$ & $\mathrm{~F}=30.000$ & 0.024 \\
\hline VEMS (1) & $1.9 \pm 0.4$ & $2.0 \pm 0.2$ & $2.0 \pm 0.7$ & $\mathrm{~F}=0.474$ & 0.205 \\
\hline VEMS/FVC (\%) & $60.80 \pm 6.14$ & $63.10 \pm 6.42$ & $76.60 \pm 5.15$ & $\mathrm{~S}_{0}=0.274$ & 0.084 \\
\hline $\mathrm{RF}(\mathrm{C} / \mathrm{min})$ & $30.3 \pm 0.5$ & $28.1 \pm 1.3$ & $27.2 \pm 0.2$ & $F=12.625$ & 0.033 \\
\hline
\end{tabular}

SP: Puberty Stage; $\mathrm{VO}_{2}$ : Oxygen Uptake; HR: Heart Rate; $\mathrm{VO}_{2}$ max: Maximum Consumption of Oxygen; FVC: Forced Vital Capacity; VEMS: Maximum Expiratory Volume per Second; RF: Respiratory Frequency. 
Table 5. Mean values and standard deviations relating to the kinetics of $\log \mathrm{VE}, \log \mathrm{VO}_{2}, \log \mathrm{V}$ $\mathrm{CO}_{2}, \log \mathrm{HR}$ and $\log \mathrm{QR}$ throughout program.

\begin{tabular}{cccccc}
\hline & BP & MP & AP & F & p-value \\
\hline $\operatorname{logVE}$ & $4.99 \pm 0.10$ & $2.87 \pm 0.03$ & $0.48 \pm 0.01$ & $\mathrm{~F}=17765.0$ & 0.025 \\
$\operatorname{logVO}{ }_{2}$ & $0.16 \pm 0.01$ & $-1.87 \pm 0.02$ & $-3.20 \pm 0.04$ & $\mathrm{~F}=32510.0$ & 0.011 \\
$\operatorname{logVCO} 2$ & $1.10 \pm 0.01$ & $-1.03 \pm 0.01$ & $-3.62 \pm 0.02$ & $\mathrm{~F}=151760.0$ & 0.029 \\
$\operatorname{logHR}$ & $4.7 \pm 0.2$ & $3.3 \pm 0.1$ & $2.2 \pm 0.1$ & $\mathrm{~F}=1099.0$ & 0.022 \\
$\operatorname{logQR}$ & $0.41 \pm 0.11$ & $0.16 \pm 0.006$ & $-0.12 \pm 0.05$ & $\mathrm{~F}=958.00$ & 0.037 \\
\hline
\end{tabular}

BP: Before Program; MP: Mid-Program; AP: After Program; VE: Ventilation Minute; $\mathrm{VO}_{2}$ : Oxygen Uptake; $\mathrm{VCO}_{2}$ : Production of Carbon Dioxide; HR: Heart Rate, QR: Respiratory Quotient.

Table 6. Characteristics of the kinetics of recovery of $\mathrm{VE}, \mathrm{HR}, \mathrm{VO}_{2}$ and $\mathrm{VCO}_{2}$ according to the category of weight.

\begin{tabular}{|c|c|c|c|c|c|}
\hline & $\begin{array}{l}<66 \mathrm{~kg} \\
(\mathrm{n}=4)\end{array}$ & $\begin{array}{c}66-80 \mathrm{~kg} \\
(\mathrm{n}=6)\end{array}$ & $\begin{array}{l}>80 \mathrm{~kg} \\
(\mathrm{n}=4)\end{array}$ & F & p-value \\
\hline \multicolumn{6}{|l|}{$\mathrm{VE}$} \\
\hline$\tau_{1}(\min )$ & $2.11 \pm 0.09$ & $1.73 \pm 0.04$ & $1.42 \pm 0.04$ & $\mathrm{~F}=80.0$ & 0.021 \\
\hline$\tau_{2}(\min )$ & $6.99 \pm 2.39$ & $6.45 \pm 1.06$ & $5.20 \pm 0.57$ & $\mathrm{~F}=2.154$ & 0.164 \\
\hline$T_{\Delta}(\min )$ & $3.24 \pm 0.21$ & $2.31 \pm 0.18$ & $1.84 \pm 0.26$ & $\mathrm{~F}=33.0$ & 0.032 \\
\hline$T_{t o t}(\min )$ & $35.46 \pm 11.23$ & $32.04 \pm 5.07$ & $25.81 \pm 2.89$ & $\mathrm{~F}=3.227$ & 0.043 \\
\hline \multicolumn{6}{|l|}{$\mathrm{VO}_{2}$} \\
\hline$\tau_{1}(\min )$ & $1.03 \pm 0.04$ & $1.11 \pm 0.01$ & $1.19 \pm 0.03$ & $\mathrm{~F}=40.0$ & 0.028 \\
\hline$\tau_{2}(\min )$ & $5.68 \pm 0.68$ & $5.75 \pm 0.43$ & $5.96 \pm 0.78$ & $\mathrm{~F}=0.242$ & 0.213 \\
\hline$T_{\Delta}(\min )$ & $1.03 \pm 0.21$ & $1.78 \pm 0.83$ & $2.13 \pm 0.19$ & $\mathrm{~F}=2.615$ & 0.072 \\
\hline$T_{t o t}(\min )$ & $27.21 \pm 3.34$ & $28.29 \pm 2.81$ & $29.61 \pm 3.79$ & $\mathrm{~F}=0.494$ & 0.085 \\
\hline \multicolumn{6}{|l|}{$\mathrm{VCO}_{2}$} \\
\hline$\tau_{1}(\min )$ & $1.79 \pm 0.06$ & $1.59 \pm 0.04$ & $1.38 \pm 0.07$ & $\mathrm{~F}=50.0$ & 0.003 \\
\hline$\tau_{2}(\min )$ & $3.67 \pm 0.06$ & $4.88 \pm 0.57$ & $5.28 \pm 0.80$ & $\mathrm{~F}=5.512$ & 0.044 \\
\hline$T_{\Delta}(\min )$ & $3.09 \pm 0.04$ & $2.27 \pm 0.13$ & $2.65 \pm 0.25$ & $\mathrm{~F}=24.667$ & 0.026 \\
\hline$T_{t o t}(\min )$ & $20.01 \pm 0.32$ & $25.47 \pm 2.76$ & $26.99 \pm 3.94$ & $\mathrm{~F}=4.406$ & 0.038 \\
\hline \multicolumn{6}{|l|}{$\mathrm{HR}$} \\
\hline$\tau_{1}(\min )$ & $2.69 \pm 0.35$ & $2.41 \pm 0.18$ & $2.23 \pm 0.07$ & $\mathrm{~F}=5.667$ & 0.041 \\
\hline$\tau_{2}(\min )$ & $15.83 \pm 4.46$ & $27.53 \pm 7.06$ & $45.90 \pm 14.60$ & $\mathrm{~F}=8.104$ & 0.035 \\
\hline$T_{\Delta}(\min )$ & $4.35 \pm 0.66$ & $3.11 \pm 0.40$ & $2.67 \pm 0.24$ & $\mathrm{~F}=16.400$ & 0.027 \\
\hline$T_{t o t}(\min )$ & $77 \pm 21$ & $127 \pm 32$ & $214 \pm 67$ & $\mathrm{~F}=8.271$ & 0.038 \\
\hline
\end{tabular}

VE: Ventilation Minute; $\mathrm{VO}_{2}$ : Oxygen Uptake; $\mathrm{VCO}_{2}$ : Production of $\mathrm{CO}_{2} ; \tau$. Time-constants expressed in minute; $\tau_{1}$ and $\tau_{2}$ indicate respectively phases 1 and 2 of recovery; $T_{\Delta}$ is time, in minute, to which the change of the phases of recovery intervenes; $T_{\text {tot }}$ is total time of recovery $\left(T_{\text {tot }}=4.61 \tau_{2}+T_{\Delta}\right)$.

The ventilatory mode during recovery after of the training program for judoists of group 1 is shown in Figure 1. For the judoists of more than $80 \mathrm{~kg}$, the reduction in VE during recovery was dependent primarily on a reduction in $\mathrm{V}_{\mathrm{T}}$ whereas the evolution proved to be mixed for less than $80 \mathrm{~kg}$ (reduction in $\mathrm{V}_{\mathrm{T}}$ and the frequency respiratory, 
FR).

\section{Discussion}

The aim of this study was to evaluate the effect of a training program "strength-velocity" on the cardiorespiratory adaptations in the Congolese judoists aged to 15 - 17 years. The data obtained show initially that if one reported the respiratory and ventilatory values according to the puberty stage, $\mathrm{HR}$ threshold, $\mathrm{VO}_{2}$ max, VEMS and ratio VEMS/ FVC increase according to puberty stage from SP3 to SP5. On the other hand, a decrease is noted for the respiratory frequency (RF). In addition, a regular decrease of basal $\mathrm{HR}, \mathrm{VO}_{2}, \mathrm{VE}, \mathrm{VCO}_{2}$ and $\mathrm{HR}$ max is observed during the training program. This study also reveals a significant decrease of $\mathrm{HR}$ after the training program. As regards the cardiorespiratory answers to the phase of recovery, a reduction in $\mathrm{V}_{\mathrm{T}}$ and VE is noted in the judoists of more than $80 \mathrm{~kg}$, whereas the evolution proved to be mixed at less than $90 \mathrm{~kg}$. The study calls nevertheless several limitations. Concerning the first limitation, it is established that the training in judo comprises efforts of the static type as well as those of dynamic type. It also requires exercises of the anaerobic type (contractions with opposition, sprint, jump) that those of aerobic type. In addition, it appears exercises of flexibility (gymnastic) and agility (acrobatics on the ground), as well as the body-building. Thus, numerous authors qualify the judo of "multiple sport" [18]. Others classify judo among the sports with particular cardiac requirement, characterized by a limited progression by physical contingencies or the fact that the respiratory mechanical function is opposed and blocked [3]. This is why, it would have been necessary to describe the modifications of the function ventricular left (FVL) by the means of measurements of dimensions of the cardiac cavities, for better appreciating the repercussions of the "strength-velocity" training program over the variations of the HR like it suggested Fagard [19] and Snoeckx [20]. This limitation of the study is associated the expensive cost of the echocardiographic-Doppler examinations in Brazzaville (80 USD). As report data of United Nations of Development Program, Congo has a human development index (HDI) of 1.30; witch ranks $137^{\text {th }}$ in the world ranking in relation to sustainable development by 2011 [21]. The second limitation is linked to no blood examinations for the determination of a probable malaria status at our subjects. Indeed, the towns of Brazzaville and Pointe-Noire are located in zones of endemic malaria, with respective frequencies of $78.8 \%$ and $81.5 \%$ [22]. In so far as a consequence first of the malaria is anemia [23] and where anemia is likely to reduce the transport of oxygen [24], it is probable that a chronic malaria can reduce the aerobic performance. Our subjects can thus be feeble when they are affected by the malaria. Moreover, the study of Bongbele et al. [25] on the blood transport capacity in Congolese sportsmen high level, apparently healthy, raises that this anemia is hemolytic by nature [26], but perhaps also ferriprive. Moreover, Schmidt et al. [23] showed that the blood capacity of transport of $\mathrm{O}_{2}$ depends, inter alia, of the infested percentage of erythrocytes. Moreover, so some of our subjects could be not infested, it is possible that those suffered from other parasitizes or of deficiencies has minimum being able to explain an anemia. It is 
also probable that they were also implodes, but in sufficiently tiny proportions to make a drop thick wrongfully negative [27]. However, several studies showed that the reduction of the rate of haemoglobin induced by the metabolic disturbances caused by the malaria causes limitation of $\mathrm{VO}_{2}$ max by the means of a fall of the affinity of haemoglobin [27]. It would be then suitable to determine total number of erythrocytes, haemoglobin concentration, mean erythrocytary volume, hematocrite and blood capacity of transport of oxygen. The third limitation milked with the respiratory results. In a general way, those of group 1 were to be interpreted with values of reference recorded in the "healthy" judoists of group 2 who have the same anthropometric characteristics as the judoists of group 1 and, if necessary, to belong to the same ethnic group. However, the principal forces of this study hold in several points. First of all, no study, to our knowledge, brings back results associated with the effects of training in "strength-velocity" on the cardiorespiratory adaptations in high level black judoists involved in full growth. Moreover, no data were available in sub-Saharan Black African countries which take account of the puberty stage in the respiratory adaptations at the high level sporting teenagers. Consequently, the limitations quoted above do not deteriorate of anything the relevance and the reliability of our data.

This study revealed a significant decrease of $\mathrm{HR}$ at rest, reaching after the training program value of $51.2 \pm 0.7 \mathrm{~b} / \mathrm{min}$. Fauchard et al. [28] reported mean value of HR equal to $53.5 \pm 6.4 \mathrm{~b} / \mathrm{min}$ in French judoists aged 11 to 17 years old, of which technico-tactic sequences are made up of short intermittent exercises (5 to $10 \mathrm{~s}$ ), vertical or horizontal jumps, sprints or the races with $100 \%$ of $\mathrm{VO}_{2}$ max. Kingue et al. [29], in 14 male Cameroonians judoists, aged $16.8 \pm 1.2$ years old, note value of basal HR to $56.75 \pm$ $5.60 \mathrm{~b} / \mathrm{min}$. These judoists were members of the Cameroonians team of judo in the category of light, selected for the championships of judo of Dakar (Senegal) of July 2008. Our values are also comparable with those presented by Gavarry et al. [30] for Belgian judoists of comparable age: $53.1 \pm 0.4 \mathrm{~b} / \mathrm{min}$. On the other hand, they are definitely lower than those brought back by Stratton [31], $66.4 \pm 2.0 \mathrm{~b} / \mathrm{min}$. The differences observed are associated nature of the drives and the sporting calendars (participation in the various competitions). However, the basal HR to our athletes is lower than that of the sedentaries. This observation is well established at the majority of the sportsmen [32], of the parasympathetic fact not only of one hypertonicity but also of a sympathetic nervous hypotonia. Our results make it possible to appreciate the effect of the various training sessions on the cardiac cost and confirm that the judo became sport demands on short-term anaerobic power and ability to recovery during twenty last decades.

The temporal analysis of the various ventilatory and respiratory variables indicates also a significant reduction in the $\mathrm{VE}, \mathrm{V}, \mathrm{VO}_{2}, \mathrm{VCO}_{2}$ and $\mathrm{RQ}$ throughout the period of experimentation. For example, the evolution of the $\mathrm{VO}_{2}$ given starting from a nonlinear regression, obeyed the following model of mono type exponential [33]: $\mathrm{VO}_{2}(t)=A_{0}+$ $A_{1}[1-\exp -(t-T D / \tau)]$, where $A_{0}$ correspond to the value of basal $V_{2}, A_{1}$ with the amplitude between $\mathrm{A}_{0}$ and the asymptomatic value of the function. TD and $\tau$ represent respectively during of time and time-constant expressed in seconds. 
However, classically there is no ventilatory limitation during the exercise. Nevertheless, the concept of a systematic increase in the alveolo-arterial difference, $\mathrm{D}(\mathrm{A}-\mathrm{a}) \mathrm{O}_{2}$, during the exercise tests is old [34]. The appearance of a hypoxemy in our juniors' judoists represents probably only the simple increase of this phenomenon which it is essential to include/understand. The role of an inequality of ratio ventilation/perfusion was highlighted by Rittel and Watterlo [35], Seliger et al. [36]; but this factor as well as possible explains only $25 \%$ of the increase in $\mathrm{D}(\mathrm{A}-\mathrm{a}) \mathrm{O}_{2}$. A haemodynamic cause is then also possible, taking into account the very significant cardiac flows developed by our judoists; what is accompanied by a rise in the pressure in the pulmonary artery.

In addition, in our study, the values of the $\mathrm{VO}_{2}$ were slightly higher than compared to the others, but not significantly. The cardiovascular responses appeared also significant with mid-program. At this period, the judoists are with a high percentage of the $\mathrm{VO}_{2}$ max. These results had also suggested by Müller Deck [37] in ground techniques of judo, which notes a peak of $\mathrm{VO}_{2}$ of $2.8 \pm 0.5 \mathrm{l} / \mathrm{min}$. However, the study does not make it possible to in general highlight an effect of work provided on the kinetics of oxygen. Moreover, according to the individual characteristics, it seems that metabolic adaptation to the exercise is influenced by puberty maturation. The results on this subject achieve the unanimity [38] [39]. Several explanations of this observation were proposed: a deficiency on the level of the phosphofructokinase [40], an earlier use of aerobic system [41], a faster oxidation of the pyruvate in young subjects compared to adult subjects [42] and a weaker sympathico-adrenergic activity in children and teenagers. The category of weight also plays a role, though this observation is not objectified in this work. Indeed, according to Thomas et al. [38], the $\mathrm{VO}_{2}$ varies according to importance of the request of the muscular groups. The same report is raised for the VE, $\mathrm{V}_{\mathrm{T}}$, $\mathrm{RF}$ and the RQ. Like the $\mathrm{VO}_{2}$, ventilation and its components, $\mathrm{V}_{\mathrm{T}}, \mathrm{RF}$ and the RQ evolves in a similar way. Indeed, the energy adaptation depends, in a general way, that of the cardiorespiratory parameters which come into play to bring oxygen necessary to muscular work. Our values of $\mathrm{VO}_{2}$ max are similar to those obtained in other longitudinal studies in the junior Mauritians [43] and Senegalese judoists [43]: $58.2 \pm 2.0$ $\mathrm{ml} / \mathrm{kg} / \mathrm{min}$ and $56.4 \pm 1.3 \mathrm{ml} / \mathrm{kg} / \mathrm{min}$, showing thus that our teenagers are well involved judoists.

Concerning evolution of the cardiorespiratory parameters during recovery, it is in conformity with what is usually described [44]. For example, $\mathrm{VO}_{2}$ decrease according to biexponential law in our judoists and turns over indeed to the control values into 5 to 10 minutes according to subjects'. It should be noted that notable difference between theoretical time of recovery $\left(\mathrm{T}_{\text {tot }}\right)$ and necessary time observed to recover $96 \%$ to $98 \%$ of $\mathrm{VO}_{2}$ or $\mathrm{VE}$ is dependent on multiexponential form of recovery and its mathematical solving. Finally, the speed of elimination of $\mathrm{CO}_{2}$ also depends on the chemosensibility of the subjects and their ventilatory capacity. However, the metabolic factors responsible for evolution of $\mathrm{VO}_{2}$ during recovery are discussed [45] [46].

\section{Conclusion}

The "strength-velocity" training program in Congolese judoists aged 15 - 17 years has 
effects on the respiratory and ventilatory adaptations, not noxious to level of health of young sportsman. Nevertheless, more rigorous medical follow-up proves to be necessary to improve the insufficiencies of the methods of training observed by the technical experts of the national team.

\section{References}

[1] Lounana, J. and Medelli, J. (2000) L’enfant, son corps et le sport. Soins Pédiatrie-Puériculture, 193, 13-15.

[2] Sallis, J.F. and Patrick, K. (2004) Physical Activity Guidelines for Adolescents. Pediatric EXercise Science, 16, 1032-1046.

[3] Ferry, A. (1999) Performance et entraînement physiques et sportifs en force-vitesse (puissance). Science \& Sports, 14, 115-129. http://dx.doi.org/10.1016/S0765-1597(99)80053-7

[4] Bigard, A.X. and Keulmann, N. (2006) Adaptations biochimiques et structurales du muscle à l'entraînement en force. Science \& Sports, 21, 50-56.

http://dx.doi.org/10.1016/j.scispo.2005.12.002

[5] Campos, G.E.R., Luccke, T.J., Wendle, H.K., Toma, K., Hagerman, F.C., Murray, T.F., et al. (2002) Muscular Adaptations in Response to Three Different Strength-Velocity Training Regimens: Specificity Repetition Maximum Training Zones. European Journal of Applied Physiology, 88, 50-60. http://dx.doi.org/10.1007/s00421-002-0681-6

[6] Thompson, H.S., Maynard, E.B., Morales, E.R. and Scordilis, S.P. (2003) Exercise-Induced HSP27, HSP70 and MAPK Responses in Human Skeletal Muscle. Acta Physiologica Scandinavica, 178, 61-72. http://dx.doi.org/10.1046/j.1365-201X.2003.01112.x

[7] Favre-Juvin, A., Majean, H., Gaillat, L. and Eterradossi, J. (1990) Approche physiologique du judo sur le terrain. Sport Medicine, 49, 28-32.

[8] André, J.L., Deschamps, J.P. and Gueguen, R. (2000) La tension artérielle chez l'adolescent sportif de haut niveau. Valeurs rapportées à l'âge et à la taille chez 1706 sportifs. Archives de Pédiatrie, 57, 477-482.

[9] Sherman, C.B., Tosteson, T.D. and Tager, I.B. (2008) Early Predictors of Factors Affecting the Development of Lung Function in Younger Judoists. American Journal of Human Biology, 20, 716-725. http://dx.doi.org/10.1002/ajhb.20804

[10] Kobayashi, K., Kiyakazu, K., Mochiyoshi, M., Hirishi, S. and Yutaka, M. (1978) Aerobic Poqer as Related to Body Growth and Training in Japanese Boys: A Longitudinal Study. Journal of Applied Physiology, 44, 666-672.

[11] Plée, T. and Melin, V. (2001) Judo Kodokan. La bible du judo. Edité sous l'autorité du Comité d’Edition du Kodokan. Budo Editions, Noisy-sur-Ecole, France, 262 p.

[12] Tanner, J.M. and Whitehouse, R.H. (1976) Clinical Longitudinal Standards for Height, Weight, Height Velocity, Weight Velocity and Stages of Puberty. Archives of Disease in Childhood, 51, 170-179. http://dx.doi.org/10.1136/adc.51.3.170

[13] Bigard, A.X., Duvallet, A., Jousselet, F., Messner, P., Préfaut, C. and Verdier, J.C. (1992) Détermination de l'aptitude médicale à la pratique du sport. Science \& Sports, 7, 59-69. http://dx.doi.org/10.1016/S0765-1597(05)80144-3

[14] Arsac, L.M., Belli, A. and Lacour, J.R. (1996) Muscle Function during Brief Maximal Exercise: Accurate Measurements on a Friction-Load Cycle Ergometer. European Journal of Applied Physiology, 74, 100-106. http://dx.doi.org/10.1007/BF00376501

[15] Vandewalle, H., Pérès, G., Sourabié, B., Stouvenel, O. and Monod, H. (1989) Force-Velocity Relationships and Maximal Anaerobic Power during Cranking in Young Swimmers. Inter- 
national Journal of Sports Medicine, 10, 439-445. http://dx.doi.org/10.1055/s-2007-1024940

[16] Sokal, R.R. and Rohlf, S.W. (1995) Biometry. 7th Edition, Freemann and Co., San Francisco.

[17] ATS/American Thoracic Society (1991) Lung Function Testing: Selection of References Values and Interpretative Strategies. American Review of Respiratory Diseases, 144, 12021218. http://dx.doi.org/10.1164/ajrccm/144.5.1202

[18] Spiro, S.G. (1997) Exercise Testing in Clinical Medicine. British Journal of Diseases of the Chest, 91, 145-172.

[19] Favre-Juvin, A. (1990) Puissance et capacité anaérobie du judoka, comparaison de données de terrain et de laboratoire. Rapport de DEA de biologie de l'exercice musculaire. University of Saint-Etienne-Lyon I.

[20] Snoeckx, L.H. (1983) Cardiac Dimensions in Athletes in Relation to Variation in Their Training Program. European Journal of Applied Physiology, 52, 20-28.

[21] UNDP (2011) Human Development Report 2011. Sustainability and Equity: A Better Future for All. UNDP, New York, $176 \mathrm{p}$.

[22] Direction de la Lutte contre les Maladies (2012) Rapport sur la lutte contre le Paludisme, $2^{\text {ème }}$ trimestre 2012. Programme National de Lutte contre le Paludisme, Ministère de la Santé et de la Population. Brazzaville.

[23] Schmidt, W., Correa, R., Böning, D., Ehrich, J.H.H. and Krüger, C. (1994) Oxygen Transport Properties in Malaria-Infected Rodents. A Comparison between Infected and Noninfected Erythrocytes. Blood, 83, 3745-3752.

[24] Lynch, M.J., Raphael, S.S., Mellor, L.D., Spar, P.D. and Inwood, M. (1976) Techniques de laboratoire médical et pathologie clinique. Tome I, 2nd Edition, Maloine, Paris.

[25] Bongbele, J., Ewamela, A., Diakoundila, E. and Mankele, R. (1998) Capacité sanguine de transport d'oxygène chez des sportifs infestés par la malaria. Revue des Maladies Respiratoires, 15, 57-59.

[26] Mehta, S.R., Ahuja, R.C., Khrisnan, N.R., Subramanian, A.R. and Naidu, G. (1987) Exercise Provocation Test for Clinical Malaria. Journal of the Association of Physicians of India, 35, 205-206.

[27] Heller, J., Peric, T., Dlouha, R., Kohlikova, E., Melichna, J. and Novakova, H. (1998) Physiological Profiles of Male and Female Judoists. Journal of Sports Sciences, 16, 243-249.

[28] Fauchard, L., Léger, L.L., Bouchard, C. and Cazorla, S. (1999) Aptitude physique des étudiants français en éducation physique et sports. Sciences et Techniques des Activités Physiques et Sportives, 49, 25-32.

[29] Kingue, S., Binam, F., Nde Ndjiele, J.F. and Atchou, G. (2001) Etude échographique de la fonction ventriculaire gauche d'un groupe de judokas camerounais. Science \& Sports, 16, 10-15. http://dx.doi.org/10.1016/S0765-1597(00)00041-1

[30] Gavarry, L., Hagberg, J.M. and Hickson, R.C. (2000) Cardiovascular Assessment in Trained Athletes. Australian \& New Zealand Journal of Medicine, 30, 540-547. http://dx.doi.org/10.1016/S0765-1597(00)00041-1

[31] Stratton, J. (1996) Etude échographique du cœur du judoka. In: Raffoul, H. and Aberg, E., Eds., Encyclopédie pratique d'écho-Doppler cardiaque, LEN Medical, Cardiologie Pratique, Paris, 15, 1-8.

[32] Pearson, A.C., Schiff, M., Mrosek, D., Labovitz, A.J. and Williams, G.A. (1996) Heart Rate and Arterial Pressure in Judoists Aged 15-19 Years Old. American Journal of Cardiology, 68, 2954-2959. 
[33] Bernard, O., Maddio, F., Ouattara, S., Jimenez, C., Charpenet, A., Melin, B. and Bittel, J. (1998) Influence of the Oxygen Uptake Slow Component on the Aerobic Energy Cost of High Intensity Submaximal Treadmill Running in Humans. European Journal of Applied Physiology, 78, 578-585. http://dx.doi.org/10.1007/s004210050464

[34] Hughson, R.L. (2000) Exploring Cardiorespiratory Control Mechanisms through Gas Exchange Dynamics. Medicine \& Science in Sports \& Exercise, 32, 72-79.

[35] Rittel, H.F. and Watterlo, H.E. (2005) Radiotelemetric bie tischtennis, tennis und badminton-spielen. Sportatz Sportmededizin, 32, 1644-1649.

[36] Seliger, V., Ejen, M., Pauer, M. and Safarik, V. (2003) Energy Metabolism in Table Tennis. Internationale Zeitschrift für Angewandte Physiologie, 61, 1333-1340.

[37] Muller Deck, P. (1990) Exploration du métabolisme énergétique chez le sportif de haut niveau. Insep Publications, Paris.

[38] Majean, H., Gaillat, L., Callec, C., Eterradossi, J. and Favre-Juvin, A. (1990) Approche physiologique du judo sur le terrain. Sport et Médecine, 49, 28-32.

[39] Cooper, D.M., Weiler-Ravell, D., Whipp, B.J. and Wasserman, K. (2004) Aerobic Parameters as a Function of a Body Size during Growth in Adolescents. Journal of Applied Physiology, 76, 628-634.

[40] Erickson, B.O., Karlsson, J. and Saltin, B. (2001) Muscle Metabolites during Exercise in Postpubertal Boys. Acta Paediatrica Scandinavica, 247, 154-157.

[41] Macek, M. and Vavra, J. (2001) Cardiopulmonary and Metabolic Changes during Exercise in Children 12-16 Years Old. Journal of Applied Physiology, 60, 200-204.

[42] Haralambie, G. (2002) Enzyme Activities in Skeletal Muscle of 13-15 Years Old Adolescents. Bulletin Européen de Physiopathologie Respiratoire, 38, 65-74.

[43] Dao, S., Brondani, J.C., Kujala, U.M. and Fall, A. (2002) Cardiorespiratory Surveillance at African Judo Event. Bulletin Européen de Physiopathologie Respiratoire, 28, 65-74.

[44] Berg, K.E. (1991) Comparison of Cardiorespiratory Values in Men and Women at Rest and during Exercise Recovery. Journal of Sports Medicine and Physical Fitness, 31, 351-356.

[45] Bangsbo, J., Johansen, L., Graham, T. and Saltin, B. (2003) Lactates and $\mathrm{H}^{+}$Effluxes from Human Skeletal Muscles during Intense, Dynamic Exercise. Journal of Physiology, 472, 115-133.

[46] Gaesser, G.A. and Brooks, G.A. (2004) Metabolic Bases of Excess Post-Exercise Oxygen Consumption: A Review. Medicine \& Science in Sports \& Exercise, 36, 29-43. 
Submit or recommend next manuscript to SCIRP and we will provide best service for you:

Accepting pre-submission inquiries through Email, Facebook, LinkedIn, Twitter, etc.

A wide selection of journals (inclusive of 9 subjects, more than 200 journals)

Providing 24-hour high-quality service

User-friendly online submission system

Fair and swift peer-review system

Efficient typesetting and proofreading procedure

Display of the result of downloads and visits, as well as the number of cited articles

Maximum dissemination of your research work

Submit your manuscript at: http://papersubmission.scirp.org/

Or contact jbm@scirp.org 